ENTREPRENEURSHIP AND SUSTAINABILITY ISSUES

ISSN 2345-0282 (online) http://jssidoi.org/jesi/ 2019 Volume 7 Number 2 (December) http://doi.org/10.9770/jesi.2019.7.2(2)

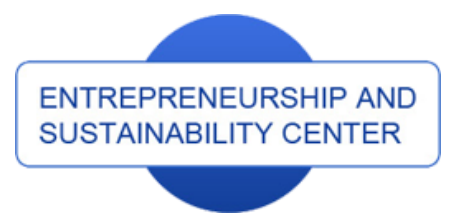

Publisher

http://jssidoi.org/esc/home
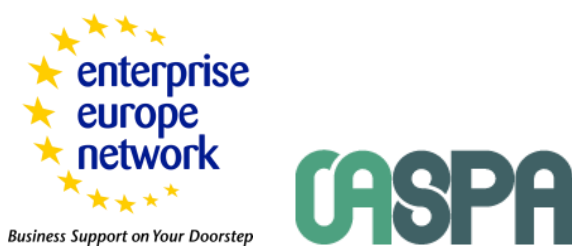

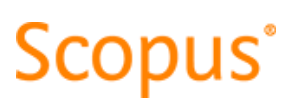

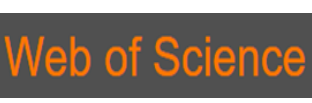

1) Clarivate

Analytics

\title{
SUSTAINABLE AGRICULTURE IN RUSSIA: RESEARCH ON THE DYNAMICS OF INNOVATION
} ACTIVITY AND LABOR PRODUCTIVITY

\author{
Boris A. Kheyfets ${ }^{1}$, Veronika Yu. Chernova ${ }^{2}$ \\ ${ }^{1}$ Institute of Economics of the Russian Academy of Sciences, 32 Nakhimovsky Prospect, Moscow, 117218, Russian \\ Federation \\ ${ }^{1}$ Financial University under the Government of the Russian Federation, 49 Leningradsky Prospect, Moscow, 125993, \\ Russian Federation \\ ${ }^{2}$ Peoples' Friendship University of Russia, 6, Miklukho-Maklaya Str., Moscow, 117198, Russian Federation \\ ${ }^{2}$ State University of Management, 99, Ryazanskiy prospect st., Moscow, 109542, Russian Federation
}

E-mails: bah412@rambler.ru; veronica.urievna@mail.ru

Received 16 March 2019; accepted 10 September 2019; published 15 December 2019

\begin{abstract}
The article examines the dependence of the growth rates of labor productivity on the growth rates of investments in fixed assets in Russian agriculture. The approach used in this work to assess the intensity of innovation activity in agriculture is based on the ratio of investment efforts and the resulting dynamics of labor productivity. It is revealed that in the period from 2013 to 2017 , the growth rates of investments in fixed assets significantly exceeded the growth rates of productivity in the industry. The study of the dependence of the growth rates of labor productivity on the growth rates of investments in fixed assets showed a rather close relationship between these indicators (the correlation coefficient $\mathrm{R}=0.57$ ). The average coefficient of elasticity shows that given a change in the growth rate of investment in fixed assets by $1 \%$ of its average value, the growth rate of labor productivity in the period from 2013 to 2017 changed on average by $0.059 \%$. The situation in Russian agriculture shows that in recent years, against the background of significant investments in fixed assets and growth of physical capital, the quality of this capital remained at a low level and could not ensure high and long-term growth in labor productivity. Additionally, an assessment of the intensity of innovation activity was conducted and an analysis of the factors was made, hindering the spread and introduction of breakthrough digital technologies.
\end{abstract}

Keywords: agriculture; digital technologies; innovation activity; labor productivity

Reference to this paper should be made as follows: Kheyfets, B.A., Chernova, V.Y. (2019). Sustainable agriculture in Russia: research on the dynamics of innovation activity and labor productivity. Entrepreneurship and Sustainability Issues, 7(2), 814-824. http://doi.org/10.9770/jesi.2019.7.2(2)

JEL Classifications: Q10, O30, J29 


\section{ENTREPRENEURSHIP AND SUSTAINABILITY ISSUES}

ISSN 2345-0282 (online) http://jssidoi.org/jesi/

2019 Volume 7 Number 2 (December)

http://doi.org/10.9770/jesi.2019.7.2(2)

\section{Introduction}

A key factor in economic growth is the introduction of digital technologies (Litau, 2018; Romanova et al., 2017; Petrenko et al., 2019). Digitalization opens up new opportunities at the level of interaction between enterprises, both in the format of horizontal cooperation within the framework of regional production and product clusters and within the framework of vertical cooperation between the links in the chains of creating added value.

The current level of digitalization of agriculture in Russia raises serious concerns. According to Rosstat, in 2017 the amount of investment in information and communication technologies of the AIC amounted to 3.6 billion rubles $(0.5 \%$ of total investments in fixed assets). This is the minimum indicator in the industries, which indicates a low digitalization of the AIC (Rosstat, 2019). There is a number of factors in Russia, such as acute shortages of qualified personnel, low attractiveness of labor in the industry, the reduced life expectancy of the rural population and migration outflow of rural residents to the cities, that force agriculture to introduce digital, intellectual and robotic labor-saving technologies at an accelerated pace. Failure to meet the high production requirements adopted in the markets of foreign countries is an obstacle to the development of exports and can lead to crisis phenomena in domestic industries with high potential and dynamics of rapid growth as the domestic market is saturated (Ministry of Agriculture of Russia, \& National Research University "Higher School of Economics", 2017).

These reasons predetermined the goal of the research - to evaluate the intensity of innovation activity in Russian agriculture. It is important to analyze the factors that impede the proliferation and introduction of breakthrough digital technologies by agricultural producers and suggest solutions to this problem.

\section{Literature review}

Since the beginning of the 2010s, digital technologies have been actively used in agriculture. Development in agriculture goes in parallel with the digital revolution in industry. Just as Industry 4.0 creates a so-called "smart factory", "Agricultural 4.0" creates a "smart farm enterprise" (TongKe, 2017). In addition to this term, such terms as "smart agriculture" and "digital agriculture" are often used (Kovács, \& Husti, 2018; Pivoto et al., 2018).

The issues of development and introduction of innovative technologies in agriculture are reflected in many works (for example, Ognivtsev, 2018; Nikitin, \& Ognivtsev, 2018; Harold et al., 2016; TongKe, 2017). The role of digital technologies in the agri-food sector is discussed in detail in the article by Kovács and Husti (2018). The interest of the researchers is attracted by the factors hindering the widespread introduction and use of digital technologies. The work is devoted to the search for prospects for digitalization for small and medium-sized enterprises (Nielson et al., 2018).

The studies on the differences in the economic growth of different countries and the role of capital accumulation and innovation in this process are widely presented in the economic literature (for example, Kumar, \& Russell, 2002; Beaudry et al., 2005; Battisti et al., 2018; Bessonov et al., 2009; Zaitsev, 2016; Lavrovskii, 2018 and others). Acceptance of the decomposition of the contribution of technological progress and the accumulation of capital in the dynamics of factor productivity is widely used in scientific research. In this case, the authors use different assessment methods in different countries. Thus, Kumar and Russell (2002) use data for the period from 1965 to 1990 and come to the conclusion that capital accumulation plays a key role in productivity growth (78\%), whereas the role of the technological development factor in their research makes up only $22 \%$. Beaudry et al. (2005) also explain the differences in the economic growth of countries by capital accumulation. In other works, the factor of technological development in economic growth is given a more significant role - 44\% (Battisti et al., 2018). 


\section{ENTREPRENEURSHIP AND SUSTAINABILITY ISSUES}

ISSN 2345-0282 (online) http://jssidoi.org/jesi/ 2019 Volume 7 Number 2 (December) http://doi.org/10.9770/jesi.2019.7.2(2)

Quite a large number of works are devoted to the assessment of innovation activity and the level of innovation development. Despite the fact that research in this direction has been conducted relatively recently, a number of methodological approaches have already been developed. In particular, the issues of assessing the level of innovation activity are considered in the works by Makoveev (2016, 2015), Sharonov (2012), Baev and Soloveva (2014), Volkova and Romanyuk (2011), Novikova (2014), Bortnik et al. (2012). The problem of using a number of methods (for example, by Volkova) is that not all indicators proposed for evaluation can be obtained. In addition, the use of weight coefficients, based on a survey of experts, introduces subjectivity in the obtained results and reduces their reliability.

It should be noted that in most publications, the assessment of innovation development is based on the aggregation of private statistical indicators (Baev, \& Soloveva, 2014; Makoveev, 2015, 2016). In the method by Makoveev, such indicators are used as the relative share of innovative products of manufacturing enterprises, the share of innovative products in the total volume of innovative products of the region, the level of innovation activity of manufacturing enterprises and the volume of shipped innovative products per an employee.

A review of the methodological approaches leads the authors to the conclusion that the assessment of the intensity of innovation activity needs to be clarified.

\section{Materials and Methods}

The approach used in this work to assess the intensity of innovation activity in agriculture is based on the ratio of investment efforts and the resulting dynamics of labor productivity.

The main provisions of the approach are based on the following reasoning: obsolete fixed assets can be reimbursed in one or another ratio based on, firstly, the latest technologies and equipment with fundamentally better specific indicators than the replaceable ones, and causing a significant increase in capital productivity; and secondly, with technologies and equipment similar to the substitutable ones, increasing productivity to a lesser extent with an increase in the capital-labor ratio. The condition for the stabilization or even reduction of capital intensity (capital-labor ratio) is the increasing efficiency of equipment and technology. Thus, the introduction of more and more modern technologies is able to slow down or even overcome the "tendency" to increase capital intensity.

The intensity of innovation activity can be measured by decomposing the increase in labor productivity into the factors generating it - the dynamics of capital productivity and the capital-labor ratio. Accordingly, the assessment of the intensity of innovation activity is part of the increase in productivity due to the dynamics of capital productivity. The more productivity growth exceeds the dynamics of the capital-labor ratio, ensuring a positive value of the rate of return on capital productivity, the higher the level (scale) of innovation activity is.

As is known, the labor productivity index $\left(I_{L P}\right)$ can be represented as a multiplication of the indices of the capitallabor ratio $\left(I_{C L}\right)$ and capital productivity $\left(I_{C P}\right)$. Thus, the assessment of the intensity of introducing innovation $\left(E_{I N}\right)$ will be considered to be the ratio of the growth rate of capital productivity to the rate of growth of labor productivity:

$$
E_{I N}=\frac{I_{C P}}{I_{L P}}
$$

The intensity of the growth of fixed assets $\left(E_{A}\right)$ will be the ratio of the growth rate of the capital-labor ratio to the growth rate of labor productivity: 


$$
E_{A}=\frac{I_{C L}}{I_{L P}}
$$

Another way to assess innovation activity is to compare the growth rate of specific investments and productivity growth. The intensity of innovation activity in terms of the growth rate of investment in fixed assets $\left(E_{F A}\right)$ is as follows:

$$
E_{F A}=\frac{K_{i} / K_{i-1}}{L P_{i}-L P_{i-1}},
$$

where $L P_{i}$ - labor productivity in the $i$-th period; $L P_{i-1}$ - labor productivity in the previous period; $K_{i}$ and $K_{i-1}-$ specific investments in fixed assets in the $i$-th period and the previous period, respectively (per employee).

To study the effect of the growth rate of investments in fixed assets on the growth rate of labor productivity, a correlation and regression analysis was applied. To determine the parameters of the model, the least squares method was used. To determine the degree of closeness of the relationship between the signs, the correlation coefficient was calculated:

$$
R_{X Y}=\frac{\overline{X Y}-\bar{X} \sqsubset \bar{Y}}{\sigma_{X} \sigma_{Y}},
$$

where $\overline{X Y}$ - mean values of $X Y ; \bar{X}, \bar{Y}$ - mean values of $X$ and $Y$, respectively; $\sigma_{X} \sigma_{Y}-$ standard deviation for $X$ and $Y$, respectively.

The average coefficient of elasticity for linear regression is calculated by the formula:

$$
\bar{E}_{Y X}=b \frac{\bar{X}}{\bar{Y}},
$$

It shows by how many percentage points the resultant attribute changes when the factor sign changes by $1 \%$ of its average value.

\section{Results and Discussion}

According to Rosstat, labor productivity in Russian agriculture for the period from 2012 to 2018 increased by 2 times, and in comparable prices in 2010 - by about 1.5 times (Table 1 ).

Table 1. Dynamics of labor productivity, investments and efficiency of using fixed assets in agriculture (in comparable prices of 2010)

\begin{tabular}{|l|r|r|r|r|r|r|}
\hline \multicolumn{1}{|c|}{ Indicator } & \multicolumn{1}{c|}{2012} & \multicolumn{2}{c|}{2013} & \multicolumn{2}{c|}{2014} & \multicolumn{2}{c|}{2015} & 2016 & \multicolumn{2}{c|}{2017} \\
\hline Labor productivity, million rubles/person & 0.47 & 0.50 & 0.53 & 0.63 & 0.66 & 0.73 \\
\hline Capital productivity, rubles/ rubles & 1.02 & 1.06 & 1.08 & 1.09 & 1.10 & 1.08 \\
\hline Capital-labor ratio, million rubles/person & 0.46 & 0.48 & 0.49 & 0.58 & 0.60 & 0.67 \\
\hline Investments in the fixed assets, million rubles & 413.62 & 429.75 & 397.07 & 348.92 & 392.61 & 430.77 \\
\hline
\end{tabular}

Source: (Rosstat, 2019)

The dynamics of investments in fixed assets was characterized by a decrease from 2013 to 2015 and its gradual growth in subsequent periods. In 2017, investment in fixed assets reached the 2013 level. Against this background, the return on fixed assets grew to 2016 inclusively, after which it was replaced by a reduction. Unlike capital productivity, the capital-labor ratio of agriculture shows a noticeable growth, especially in the 
period of 2014-2015 (the period of activation of the policy of import substitution against the background of the imposition of sanctions and a retaliatory Russian embargo). At the same time, the dynamics of the labor productivity index throughout the entire period changes in the direction of the dynamics of the capital-labor ratio. In the period of 2012-2016, the difference in growth indices is 1-4 points in favor of productivity, but already in 2017, the growth rate of the capital-labor ratio exceeds the growth rate of labor productivity (Fig. 1), which indicates that there is the growth of capital intensity against the background of lagging growth rates of labor productivity.

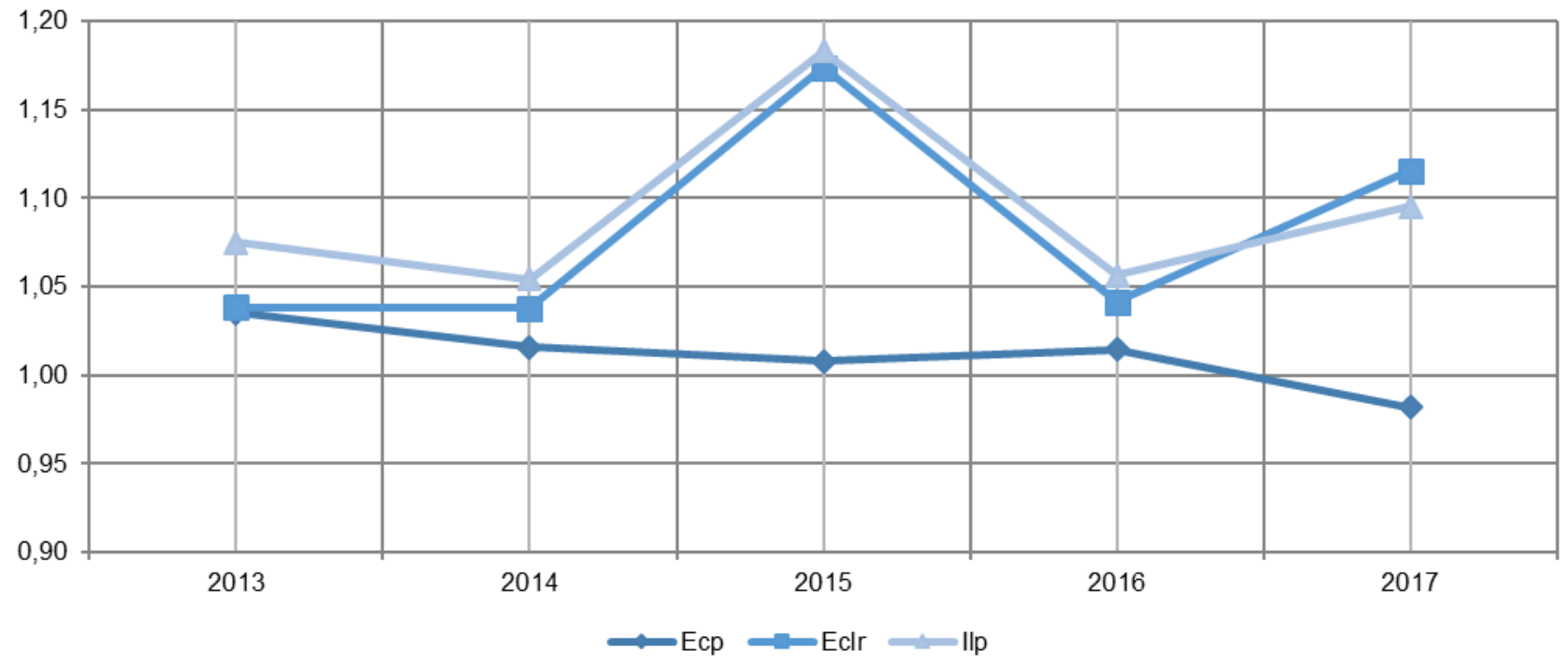

Fig. 1. Indices of growth of the capital-labor ratio, capital productivity and labor productivity in agriculture (in comparable prices)

The policy resulted in a production reduction in the industry. Thus, according to Rosstat, in 2018 , for the first time during the period of activation of the policy of import substitution, there was a decrease in output in comparable prices (Fig. 2), which was particularly significant in agricultural organizations (by $8.3 \%$ in 2018 compared to 2016) and farm enterprises (17\%), while in the households of the population there was an increase by $4.2 \%$.

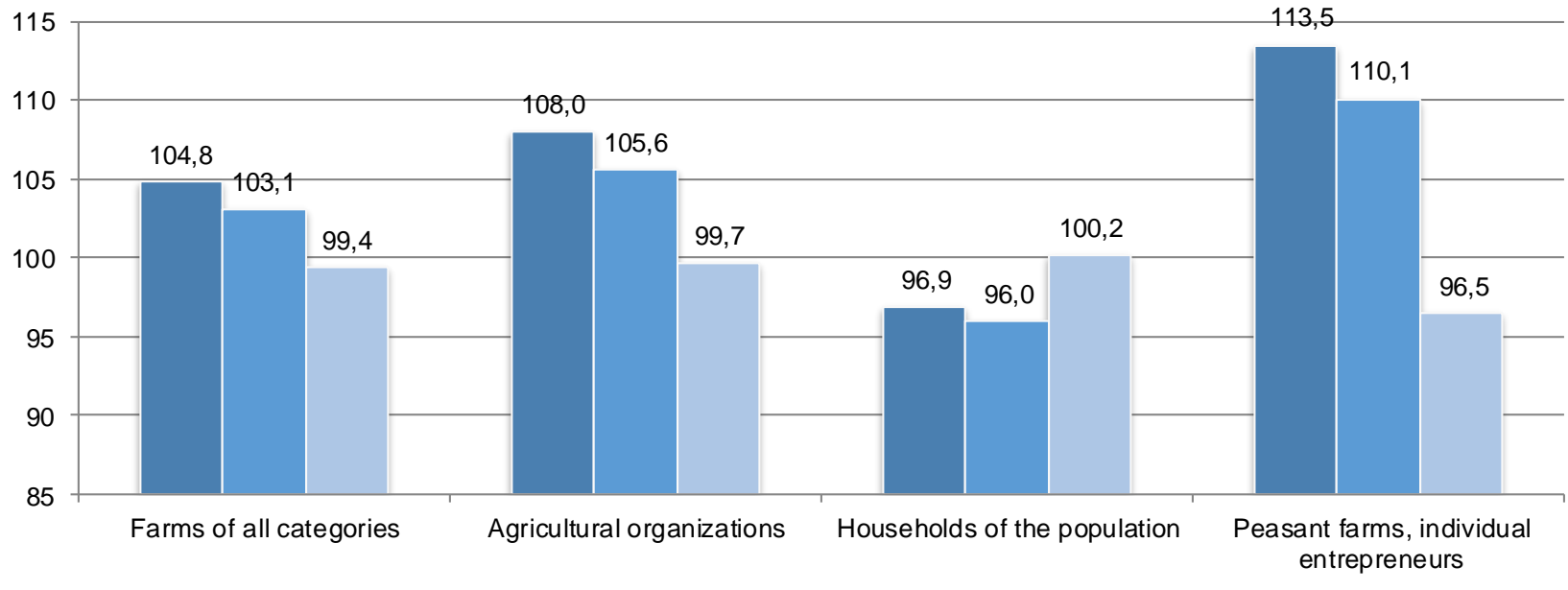

$=2016=2017=2018$ 
Fig. 2. Indices of agricultural production in farms of all categories (in comparable prices of 2010), in percentage to the previous period

Source: (Rosstat, 2019)

During the examined period, the dynamics of the intensity of introducing innovation is unstable: growth in 20142015 was replaced by its deceleration for the next year and moderate growth in 2016-2017, while the extensiveness of the growth of fixed assets during this period increases steadily at extremely low rates (Fig. 3).

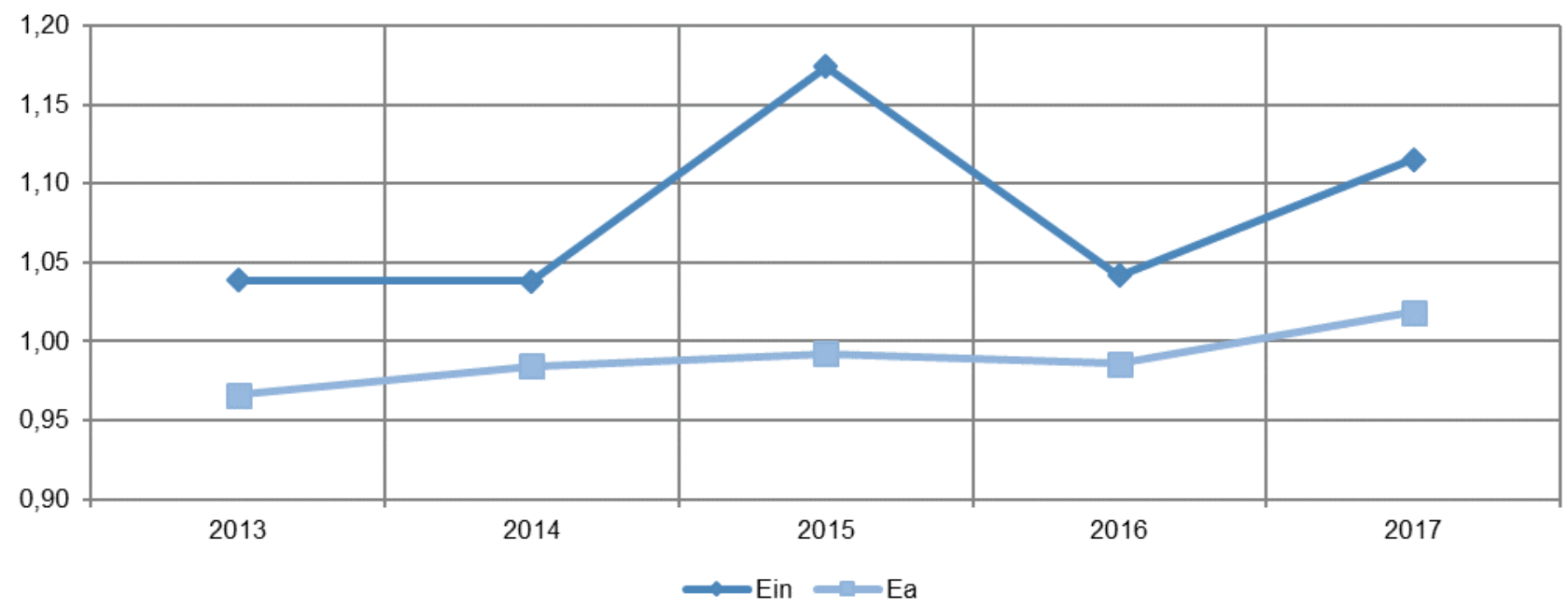

Fig. 3. The intensity of introducing innovation and the intensity of accumulating fixed assets in agriculture

Evaluation of innovation activity in agriculture on the basis of a comparison of specific investments (per person employed in agriculture) and the growth of labor productivity also showed an increase in 2015 (Fig. 4). In 2017, productivity growth in the industry was replaced by a fall, which ultimately led to a decrease in output in comparable prices in 2018.

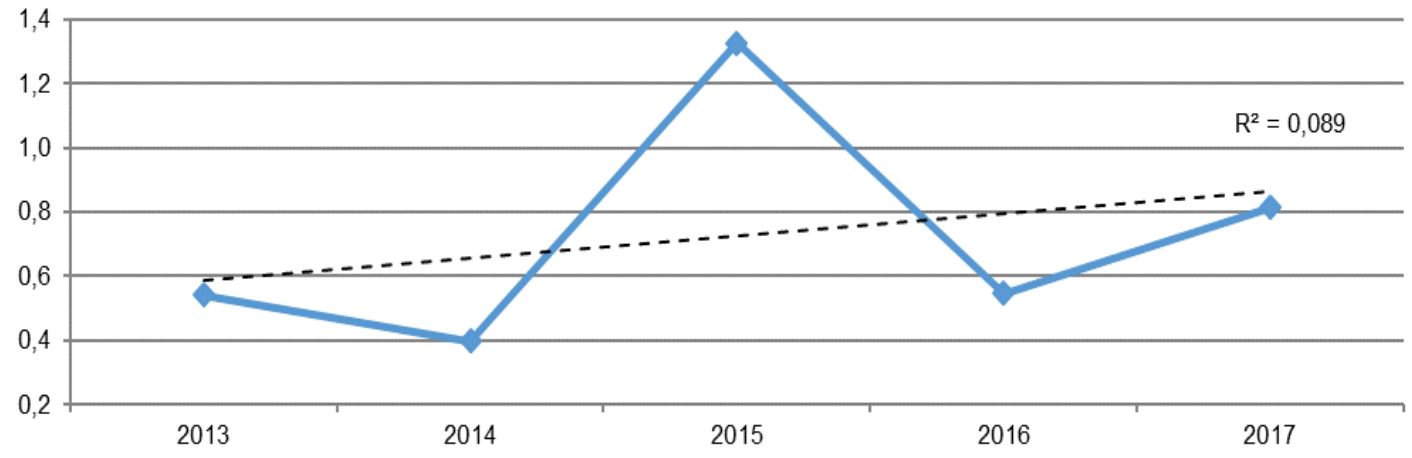

Fig. 4. The intensity of innovation activity on the basis of comparing the growth rate of specific investment (per employee) and productivity growth in agriculture

The study of the dependence of the growth rates of labor productivity on the growth rates of investments in fixed assets showed a rather close relationship between these indicators (the correlation coefficient $\mathrm{R}=0.57$ ). The graphic view of the relationship is shown in Fig. 5. The regression equation has the form $Y=0.0031+0.0637 X$. The average coefficient of elasticity $\left(\bar{E}_{Y X}\right)$ equal to 0.059 shows that with a change in the growth rate of investment in fixed assets by $1 \%$ of its average value, the growth rate of labor productivity in the period from 2013 to 2017 changed on average by $0.059 \%$; in other words, the growth rate of investments in fixed assets significantly exceeded the average growth rates of labor productivity in the industry. 


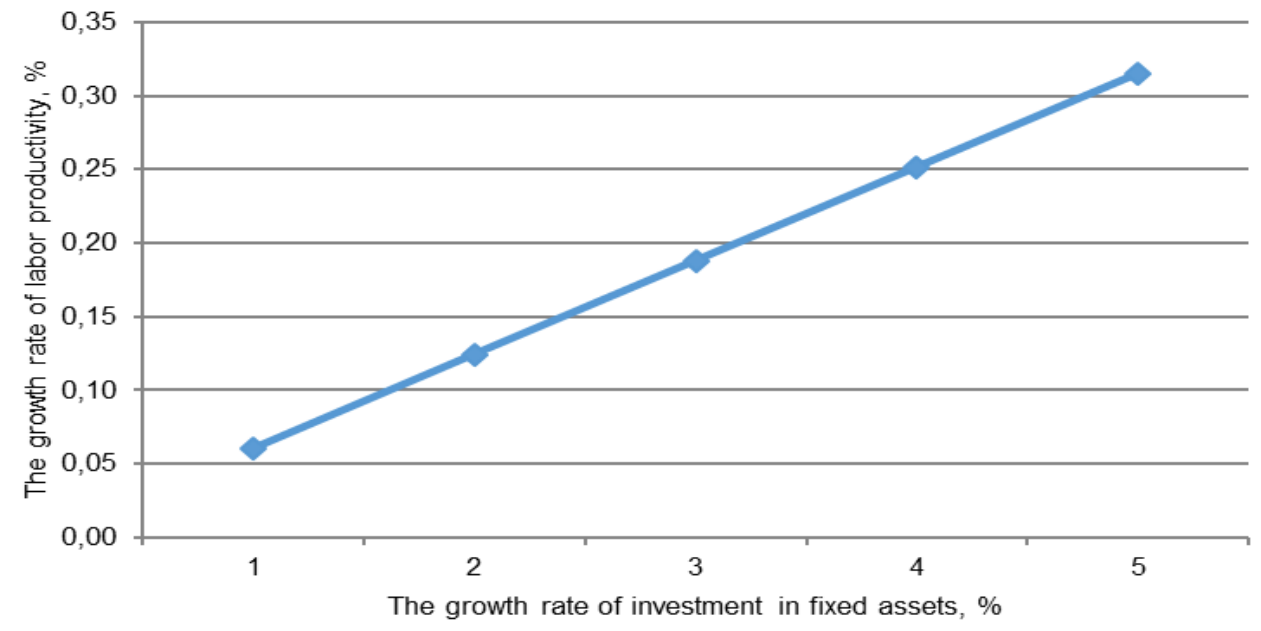

Fig. 5. The function of the dependence of the growth rate of labor productivity on the growth rate of investment in fixed assets in agriculture in the period from 2013 to 2017

The identified difficulties with maintaining the statistics in the agricultural sector should be noted. According to previously published data by Rosstat, agriculture in recent years has grown at a rapid pace. However, according to the results of the 2016 All-Russian Agricultural Census, it was revealed that some data on agricultural production (in particular, in assessing the production of potatoes, milk, vegetables, fruits and berries) were overstated and subsequently adjusted downward.

The situation in Russian agriculture shows that in recent years, against the background of significant investments in fixed assets and growth of physical capital, the quality of this capital remained at a low level and could not ensure high and long-term growth in labor productivity. The cost structure by type of innovation activity is characterized by serious imbalances: more than half of the funds $(58 \%)$ allocated for innovation are spent on the purchase of machinery and equipment (Baev, \& Soloveva, 2014; Gokhberg, \& Kouznetsova, 2009; Bessonov et al., 2009).

The reasons for this situation lie in weak innovation activity, lack of financial resources and low competitiveness of Russian innovations in the international arena (Sharonov, 2012). Russia is significantly inferior to the leading world countries in such indicators as the level of expenditure on research and development as a percentage of GDP, the relative share of organizations producing innovative goods and revenues from technology exports. The agri-food business is not encouraged to engage in innovation activity due to the lack of fierce competition in the domestic market after the introduction of the Russian ban on the import of food products from a number of Western countries, and, consequently, the lack of interest of Russian business to change something in their activities.

Comparison of the level of labor productivity in Russia and countries such as Germany, the USA, and Norway shows a gap in productivity in the economy as a whole by two to four times. This difference is by 53\% due to the lower level of technology used in Russia, by $43 \%$ - due to lower capital-labor ratio and by $4 \%$ - lower quality of human capital (Zaitsev, 2016). Higher labor productivity indicators in developed countries are provided with both large amounts of physical capital per employed person and higher quality composition of this capital, as well as more efficient management and organization of production. A more rational organization of employment and high quality of management lead to lower losses in working time and costs. Whereas, the growth of the technological level of Russia can provide an increase in labor productivity by 1.6-1.8 times (Lavrovskii, 2018). 


\section{ENTREPRENEURSHIP AND SUSTAINABILITY ISSUES}

ISSN 2345-0282 (online) http://jssidoi.org/jesi/

2019 Volume 7 Number 2 (December)

http://doi.org/10.9770/jesi.2019.7.2(2)

In addition, the quality of the institutional environment has a significant impact on labor productivity (Zaitsev, 2016; Kuzmin, \& Barbakov, 2015). With a higher quality of the institutional environment, the same level of the capital-labor ratio can produce a higher volume of output. However, as Polterovich (2012) notes, high-quality institutions are neither a necessary nor a sufficient condition, and even good institutions are not a guarantee of productivity growth and economic growth. In turn, the low quality of the institutional environment hindered the creation and development of incentives for the introduction of more advanced technologies.

The institutional barriers which weaken the incentives for innovation are as follows: 1) a reduction in investment caused by both the low profitability of private investment (Berdyugina et al., 2017) and the low savings rate, 2) a decrease in expected utility from innovation due to the existence of institutional restrictions on competition (Baltserovich, \& Zhontsy, 2012). The import substitution policy pursued since 2014 inevitably weakened competition in the domestic Russian market, creating more favorable conditions for domestic agricultural producers.

Summarizing, it can be noted that the main factors hindering the growth of the introduction of digital technologies in agriculture are as follows:

- lagging of rural areas in the development of digital infrastructure, access to digital technologies and the development of digital skills of the rural population. Significant reduction of digital inequality between rural and urban population in terms of access to the Internet and the presence of mobile devices did not reduce inequalities in the possession of basic digital skills, and digital inequality in the possession of advanced digital skills between rural and urban population continues to be very high (Sabelnikova et al., 2018);

- lack of financial resources for the introduction of digital technologies in the majority of agricultural producers. In the agro-industrial complex, a so-called bipolar economy is formed, where large agricultural organizations that have wide access to digital technologies and have been introducing them for a long time are concentrated at one pole, and at the other pole there are farms, especially small and mediumsized ones, that are working on the verge of payback using obsolete technologies.

- the level of software solutions that are currently widely available in the information and communication technologies market does not correspond to the needs of agricultural producers, who do not need separate elements of technology, but need a comprehensive solution (Chulok, 2019), etc.

\section{Conclusion}

The conducted study showed that in the period from 2013 to 2017, the growth rate of investment in fixed assets of agriculture significantly exceeded the growth rate of labor productivity. An assessment of the intensity of innovation introduction and innovation activity showed its short-term growth in 2015, its decline in 2016 and a slight recovery in 2017. The increase in the intensity of innovation activity in 2015 is associated with the intensification of the import substitution policy and the strengthening of state support for agriculture. However, after that, the import substitution policy inevitably weakened competition in the domestic Russian market, creating more favorable conditions for domestic agricultural producers. The absence of fierce competition in the domestic market and the introduction of breakthrough technologies and new-generation equipment, mainly in large agricultural holdings that received government support at the expense of small and medium-sized businesses, did not contribute to the growth of innovation activity in agriculture. Other obstacles to the development of innovation activity were the lack of financial resources, the lack of a sufficient number of Russian innovations and their low competitiveness in the international arena, with the simultaneous rise in prices for foreign technologies, and the low quality of the institutional environment. 


\section{ENTREPRENEURSHIP AND SUSTAINABILITY ISSUES}

ISSN 2345-0282 (online) http://jssidoi.org/jesi/ 2019 Volume 7 Number 2 (December) http://doi.org/10.9770/jesi.2019.7.2(2)

\section{References}

Baev, I.A., \& Soloveva, I.A. (2014). Empirical Analysis of the Relationship of Investment and Innovation Activity of the Russian Regions. Economy of the Region, 1, 147-155. https://doi.org/10.17059/2014-1-13

Baltserovich, L., \& Zhontsy, A. (Eds.). (2012). Mysteries of Economic Growth: Driving Forces and Crises - a Comparative Analysis. Moscow: Mysl. (p. 510).

Battisti, M., Del Gatto, M., \& Parmeter, C.F. (2018). Labor Productivity Growth: Disentangling Technology and Capital Accumulation. Journal of Economic Growth, 23(1), 111-143. https://doi.org/10.1007/s10887-017-9143-1

Beaudry, P., Collard, F., \& Green, D. A. (2005). Changes in the World Distribution of Output per Worker, 1960-1988: How a Standard Decomposition Tells an Unorthodox Story. The Review of Economics and Statistics, 87(4), 741-753. https://doi.org/10.1162/003465305775098116

Berduygina, O.N., Vlasov, A.I., \& Kuzmin, E.A. (2017). Investment Capacity of the Economy during the Implementation of Projects of Public-Private Partnership. Investment Management and Financial Innovations, 14(3), 189-198. Retreived June 29, 2019, from http://doi.org/10.21511/imfi.14(3-1).2017.03

Bessonov, V.A., Gimpelson, V.E., Kuzminov, Ya.I., \& Yasin, E.G. (2009). Productivity and Factors of Long-Term Development of the Russian Economy: Report for the X International Scientific Conference of the State University Higher School of Economics on Economic and Social Development Issues, Moscow, April 7-9, 2009. Moscow: Publishing House of HSE. (p. 66).

Bortnik, I.M., Senchenya, G.I., Mikheeva, N.N. et al. (2012). The System of Evaluation and Monitoring of Innovation Development of the Russian Regions. Innovations, 9, 48-61.

Chulok, A. (2019). AIC of the Future. A look at Agriculture through the Prism of Big Data Analysis. Retrieved June 29, 2019, from https://www.agroinvestor.ru/analytics/article/31304-apk-budushchego

Gokhberg, L., \& Kouznetsova, I. (2009). Innovation in the Russian Economy: Stagnation before Crisis? Foresight-Russia, 3(2), 28-46. https://doi.org/10.17323/1995-459X.2009.2.28.46

Harold, E.M., Woodard, J., Glos, M., \& Verteramo, L. (2016). Digital Agriculture in New York State: Report and Recommendations. Ithaca, N.Y.: Cornell University.

Kovács, I., \& Husti, I. (2018). The Role of Digitalization in the Agricultural 4.0 - How to Connect the Industry 4.0 to Agriculture? Hungarian Agricultural Engineering, 33, 38-42. https://doi.org/10.17676/HAE.2018.33.38

Kumar, S., \& Russell, R.R. (2002). Technological Change, Technological Catch-Up, and Capital Deepening: Relative Contributions to Growth and Convergence. American Economic Review, 92(3), 527-548. https://doi.org/10.1257/00028280260136381

Kuzmin, E.A., \& Barbakov, O.M. (2015). Institutional Efficiency and Processes of Institutional Changes (as Seen by the Russian Academic Tradition). Asian Social Science, 11(6), 163-170. https://doi.org/10.5539/ass.v11n6p163

Lavrovskii, B.L. (2018). Estimation of the Intensity of Innovation Activity (on the Example of the USA). Economy of the Region, 14(1), 281-291. https://doi.org/10.17059/2018-1-22

Litau, E. (2018). Entrepreneurship and Economic Growth: A Look from the Perspective of Cognitive Economics. In ACM International Conference Proceeding Series (pp. 143-147). Retrieved June 29, 2019, from http://doi.org/10.1145/3271972.3271978

Makoveev, V.N. (2015). Methodical Approaches to Determining the Level of Development of Innovation Activity in Manufacturing Industries. Problems of the Development of the Territory, 5(79), 125-134.

Makoveev, V.N. (2016). Factor Analysis and Assessment of the Development of Innovation Activity in the Manufacturing Industry. Regional Economics: Theory and Practice, 12(435), 143-153. 


\section{ENTREPRENEURSHIP AND SUSTAINABILITY ISSUES}

ISSN 2345-0282 (online) http://jssidoi.org/jesi/ 2019 Volume 7 Number 2 (December) http://doi.org/10.9770/jesi.2019.7.2(2)

Ministry of Agriculture of Russia, \& National Research University "Higher School of Economics". (2017). Forecast of Scientific and Technological Development of the Agro-Industrial Complex of the Russian Federation for the Period up to 2030. Moscow: HSE. (p. 140).

Nielson, D., Mane, Yu-T., Buivolova, A., \& Akopyan, A. (2018). Unlocking the Potential of Digital Technologies in Agriculture of Russia and the Search for Prospects for Small Farms. Washington: The World Bank Group. (p. 42).

Nikitin, A.V., \& Ognivtsev, S.B. (2018). The Development Strategy of the Innovative Scientific and Technological Center of the AgroIndustrial Complex. International Agricultural Journal, 3, 55-60. https://doi.org/10.24411/2587-6740-2018-13047

Novikova, I. (2014). Disproportions of the Federal Innovation Development. The Economist, 12, 46-52.

Ognivtsev, S.B. (2018). The Concept of the Digital Platform of the Agro-Industrial Complex. International Agricultural Journal, 2 , 16-22. https://doi.org/10.24411/2587-6740-2018-12019

Petrenko, Y., Vechkinzova, E., Antonov, V. (2019). Transition from the industrial clusters to the smart specialization of the regions in Kazakhstan. Insights into Regional Development, 1(2), 118-128. https://doi.org/10.9770/ird.2019.1.2(3)

Pivoto, D., Waquil, P.D., Talamini, E., Spanhol Finocchio, C.P., Dalla Corte, V.F., \& Vargas Mores, G. (2018). Scientific Development of Smart Farming Technologies and Their Application in Brazil. Information Processing In Agriculture, 5, 21-32. https://doi.org/10.1016/j.inpa.2017.12.002

Polterovich, V.M. (2012). Regional Institutes of Modernization. Bulletin of Ufa State University of Economics and Service, 1(1), $45-54$.

Romanova, O.A., Korovin, G.B., \& Kuzmin, E.A. (2017). Analysis of the Development Prospects for the High-Tech Sector of the Economy in the Context of New Industrialization. Espacios, 38(59), 25.

Rosstat. (2019). Official Statistics. Investments. Retrieved June $29, \quad 2019$, from http://www.gks.ru/wps/wcm/connect/rosstat_main/rosstat/ru/statistics/enterprise/investment/nonfinancial/

Sabelnikova, M.A., Abdrakhmanova, G.I., Gokhberg, L.M., Dudorova, O.Yu. et al. (2018). Information Society in the Russian Federation. 2018: Statistical Collection. Moscow: NRU HSE, 2018.

Sharonov, A.N. (2012). Assessment of the Level of Development of Innovation Activity of the Russian Economy. Yaroslavl Pedagogical Bulletin, 1(1), 78-82.

TongKe, F. (2017). Smart Agriculture Based on Cloud Computing and IOT. Journal of Convergence Information Technology, 8(2), 210216. https://doi.org/10.4156/jcit.vol8.issue2.26

Volkova, N.N., \& Romanyuk, E.I. (2011). The Level of Development of the Innovation System and the Specialization of the Russian Regions. Questions of Statistics, 9, 38-47.

Zaitsev, A.A. (2016). Cross-Country Differences in Labor Productivity: The Role of Capital, the Level of Technology and Natural Rent. Questions of Economy, 9, 67-93. https://doi.org/10.32609/0042-8736-2016-9-67-93 


\section{ENTREPRENEURSHIP AND SUSTAINABILITY ISSUES}

ISSN 2345-0282 (online) http://jssidoi.org/jesi/

2019 Volume 7 Number 2 (December)

http://doi.org/10.9770/jesi.2019.7.2(2)

Boris A. KHEYFETS, Professor, Dr. Sci. (Economic), Chief Researcher, Institute of Economics of the Russian Academy of Sciences (Moscow, Russia); Financial University under the Government of the Russian Federation (Moscow, Russia). Professional interests: economic globalization, risks, international relations, import substitution, TNCs, development strategies, world economy, credit policy, competitiveness, economic partnerships, industrial policy.

ORCID ID: orcid.org/0000-0002-6009-434X

Veronika Yu. CHERNOVA, Associate Professor, Cand. Sci. (Economic), People's Friendships University of Russia, Department of Marketing; Institute of Marketing, State University of Management. Professional interests: world economy, marketing of transnational companies, importsubstitution, product personalization, one-to-one marketing, interactive marketing communications. Recent articles are published in a cooperation with research colleaques in a field of retailer's communication strategies; product personalization, managing data-driven advertising campaigns.

ORCID ID: orcid.org/0000-0001-5951-9091

Register for an ORCID ID:

https://orcid.org/register

Copyright (C) 2019 by author(s) and VsI Entrepreneurship and Sustainability Center

This work is licensed under the Creative Commons Attribution International License (CC BY).

http://creativecommons.org/licenses/by/4.0/

(c) (i) Open Access 